\title{
Current Situation and Countermeasures of Rural Information Construction
}

\author{
Li Qiang ${ }^{1, a}$, Yang Kui ${ }^{1}$, Hu Juan ${ }^{2}$ \\ ${ }_{1}^{1}$ Modern Education Technology Center, Huazhong Agricultural University, Wuhan, China NM 473 \\ ${ }^{2}$ Finance Department,Huazhong Agricultural University, Wuhan, China NM 473
}

\begin{abstract}
Rural informatization is an important part of the national informatization. China's rural informatization has been paid full attention and attached great importance by the whole society. rural informatization construction has been a certain amount of base, but the full implementation of rural informatization construction is still a long way to go, both facing integration, specialization, practical, universalization significant trends, but also facing the contradictions of the majority of farmers' growing demand for information services and the level of IT. This article where start from the important significance of rural informatization, then analyzes the status quo and problems of China's rural informatization, finally puts forward some countermeasures for the construction of rural informatization.
\end{abstract}

Keywords. rural informatization; status quo; countermeasures

\section{Introduction}

Rural informatization is the process of communication technology and computer technology used in rural production, life and social management. ${ }^{[1]}$ Its essence is the application of communications, networking, information technology and other means to solve the production problems of rural life, changes from traditional agriculture to modern agriculture information. The general framework of rural information includes rural information infrastructure, resource integration and utilization, service system, professional applications and so on. The Party Central Committee has always attached great importance to the development of rural informatization, Central Document No.2008 clearly emphasized: According to seek practical, Service-oriented, wide coverage, multi-mode required, integrate resources, build a platform, improve the rural information service system. ${ }^{\left[{ }^{[2]}\right.}$ In subsequent years, Central Document is proposed for rural information specific requirements.

\section{The importance of rural informatization}

\footnotetext{
${ }^{a}$ Corresponding Author: lynx8888@163.com
} 
Rural informatization is an important part of the national informatization. Advancing the rural informatization, it is through information technology focus on the service level of improving the agricultural production and operation, quality safety control, market liquidity. To speed up construction of rural information not only help promote the strategic restructuring of the rural economy, the transformation of agricultural production, the industrialization of agriculture modernization, Prosperous rural economy, And can effectively promote the development of rural social undertakings. Rural informatization is a very important content of construction of new village, has great and far-reaching significance for urban and rural development, Also the implementation of major strategic choice for the great rejuvenation of the Chinese nation. At present rural informatization includes at least the following 6 areas: Agricultural information of science and technology education, resources and environment, Consumption of rural life, production management, administrative management, and market liquidity. ${ }^{[3]}$

\section{Status and problems of agricultural informatization construction status and existing problems}

In the 80's of the twentieth Century, Our country have put forward the informatization construction, behind the developed countries in Europe and America about 20 years, rural informatization construction started later, the gap is even larger. Until 1996 the first national work conference on rural economic information the concept and content of rural informatization construction was defined. In 2005, central file of central authorities first raised questions about rural informatization, strengthening the construction of rural informatization. These years, central authorities continue to pay close attention to rural development, rural informatization has repeated in the Central Document. Now the rural informatization construction has rapid developed, infrastructure, information services platform and the construction of rural information resources also have made some progress, these lay a foundation for building a well-off society in China. However, the rural information construction started late in our country, and it restricted by geographical, economic, many places are still in the stage of popularization and development. Therefore, the full realization of rural information is still many problems.

\subsection{Infrastructure constructions gradually perfect, but development is highly uneven}

In recent years, in the joint efforts of the central and local government, rural construction of information infrastructure is made significant progress. National, provincial, city and county are accordingly set up agricultural information centers at all levels, and started some rural information technology demonstration projects, Initially established the rural information service system. Due to the uneven development of the regional economy, it caused the rural informatization development difference. The southeast of rural infrastructure more perfect and the information service level higher. In all respects have obvious advantages than northwest underdeveloped rural areas. at the same time, northwestern rural requirements for information lower, demand is not obvious, resulting in too few countries invest in this area, rural informatization gap is widening further.

Table 1. Implemented agricultural related engineering by government in China

\begin{tabular}{|c|c|}
\hline $\begin{array}{c}\text { Agriculture-related } \\
\text { departments }\end{array}$ & The main project name \\
\hline $\begin{array}{c}\text { Ministry of Information } \\
\text { Industry }\end{array}$ & "Every Village", "benefit farmers", "Golden agriculture project", "Sunshine \\
Project"
\end{tabular}




\begin{tabular}{|c|c|}
\hline Ministry of Agriculture & $\begin{array}{c}\text { Golden agriculture project, Comprehensive rural information service platform, } \\
\text { Sunshine Project }\end{array}$ \\
\hline department of commerce & $\begin{array}{c}\text { information service system construction, the village of a thousand million rural } \\
\text { market project }\end{array}$ \\
\hline $\begin{array}{l}\text { Ministry of Land and } \\
\text { Resources }\end{array}$ & golden land project \\
\hline$\ldots \ldots$ & $\ldots \ldots$ \\
\hline
\end{tabular}

\subsection{Agricultural information resources continue to enrich, but relative lack of effective resource information}

With the state continuing to increase investment in rural areas, growing popularity of agricultural knowledge, growing spread of agricultural knowledge, agricultural Information Resources have also been continuously enriched.

\subsubsection{Various kinds of agriculture-related website}

A part of agricultural policy and information site set up by government departments, a part of agricultural science and technical guidance websites established by research and education departments, but the majority websites are built by agricultural enterprises for the purpose of profit or winning marketing or trading of the product. According to the investigation, in all agricultural information service websites, enterprise accounted for absolute dominance, about $82.6 \%$, government departments and education or research departments accounted for $11 \%$ and $2.6 \%$. Agricultural websites information resources include agricultural production, market information, technical information, policies and regulations and other resources.

\subsubsection{Agricultural database constantly enrich}

At present, China has built a national agricultural scientific data sharing center, which is to meet the national demand for agricultural science and social services. Based on the agricultural sector and the data source units, relied on the data center, through integrating, introducing, exchanging method to collect of domestic and foreign agricultural scientific data resources. ${ }^{[4]}$ Chinese Academy of Agricultural Sciences leads the Agriculture database and agricultural disc service mainly include: "China Agriculture Literature Database", "Chinese Agriculture Abstract Database", "Chinese Crop Germplasm Resources Database", "Deep processing of agricultural bibliographic database" "Directory Database of Phytosanitary Pests", etc., also introduced international famous database systems including Cabi, Agris, and Aoricola.

\subsubsection{Agricultural information resources in our country have many problems}

Due to various reasons, our agricultural information resources also exist many problems, such as information resources small-scale and scattered, unevenly distributed, the website information content serious repeat, generally to promote local agriculture, content of practical guidance and reference are too few, columns are similar, lack of feature; maintainer of agricultural information too little, update too slowly, information content manifestation too simple, lack of vivid expression, difficult to meet the needs of farmers in different cultural levels.

\subsection{Agricultural information service system in initial shape, but the basic information service supporting ability is weak}


Agricultural Information Service System is based on the development of agricultural information, providing agricultural information services as the core, according to certain operating rules and institutions composed of organic systems. ${ }^{[5]}$ Currently, Our country has set up provincial department for rural information technology service support. Talent team of agricultural information service system is constantly growing. But in the rural areas, the farmers' knowledge level is not high, lack of necessary computer knowledge, difficult to obtain benefits through information; the serious shortage of agricultural information technology professionals are hard to provide easy understanding technical, so the farmers are difficult to adapt to the new information technology which needed by development of the agricultural.

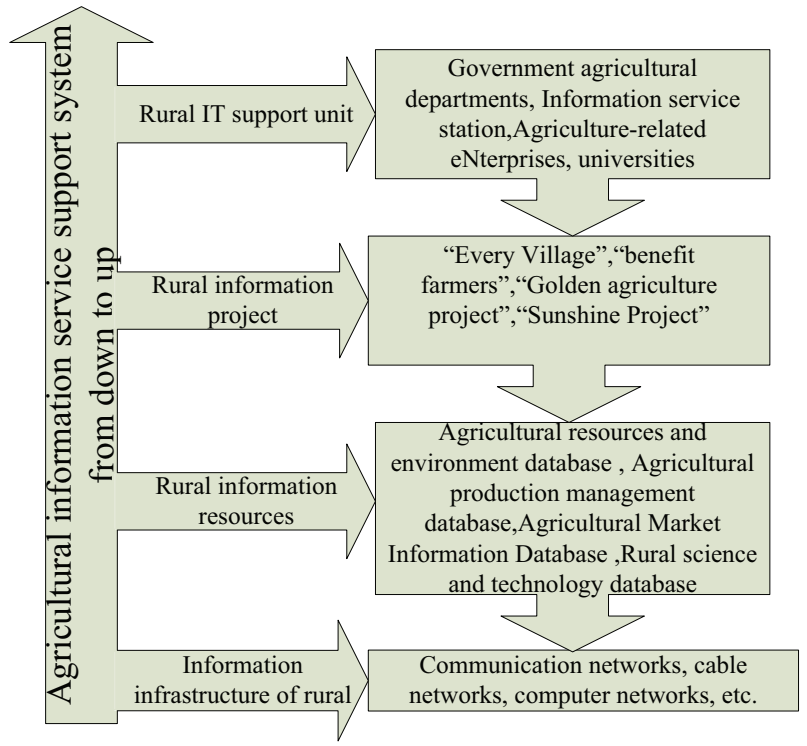

Figure 1. Agricultural information service support system from down to up

\section{Measures of information construction in rural areas}

After the text edit has been completed, the paper is ready for the template. Duplicate the template file by using the Save As command, and use the naming convention prescribed by your conference for the name of your paper. In this newly created file, highlight all of the contents and import your prepared text file. You are now ready to style your paper; use the scroll down window on the left of the MS Word Formatting toolbar.

\subsection{Improve government functions and increased construction}

The government is the organizer and participant rural informatization construction, the important function is to promote rural informatization. The Government should continue to increase efforts in building rural informatization, narrow the regional difference, gradually realize the full coverage of rural information network, provide the necessary infrastructure to improve and perfect the rural information development. First, government policy should provide a good environment for the development of investment in rural areas, give more support for the development, agricultural research in planning, and ensure that the informatization construction funds in place. Finally government should play a functional role, make health care, education, science and technology play a greater effectiveness in all aspects of rural informatization process. 


\subsection{Use the technology of university, agricultural scientific research institutes, and build rural information technology services platform}

In our country, agricultural and forestry colleges, agricultural research institutes have had to bear the responsibility of agricultural research and social services, and also as an important support for sustainable development of rural economic and social. Along with the universities, research institutes to serve the "three rural" deeply, the form and the content also constantly enriched, which guide the farmers to carry out the production activities, help farmers manage financial. They also brought informatization software and hardware to rural, established a variety of IT platform, helped farmers to develop production practice, agricultural operations, legal advisory services, such as Online Expert Advice, Trade Online Call, these have provided reliable technical support for rural information.

\subsection{Intensify efforts to introduce information technology talents in rural areas, gradually develop rural information management team, enhance the farmers' information consciousness.}

The main factors of impact and restrict the development of information technology in rural areas is still lack of information technology talents; we should pay close attention to strengthen the training of information professionals as a fundamental event. Through introducing and cultivate a group of skilled management team to understand IT, to strengthen the capacity of technology Information services in rural grassroots. With the "village official plan", "three supports and one assistance", "college students volunteer service plan" Implemented, high-level talent rooted in rural is on the increase, they can improve the information quality of rural residents to adapt to the development of information, improve the information acceptance and capacity of rural grassroots cadres and peasants. Increase rural resident information technology training and education, improving the overall quality of rural information officer. Only rural residents overall information quality is improved, and benefit from the information process, and then can mobilize their enthusiasm to promote the process of agricultural and rural informatization. Simultaneously, Increase rural residents propaganda, enhance their awareness of information, guide them to take the initiative to understand the market information, information technology, make farmers really benefit from rural informatization, at last formed a good social environment of rural information.

\subsection{Use technology to simplify and optimize of information resources}

Although the overall knowledge level of farmers are relatively low, but information needed more urgent. Today wide range of practical information and technology of agricultural are too professional, hard to understand. With the development of information and multimedia technology, agricultural information technology can be screened first, and manifested in a vivid, concise, understandable way, which will help farmers easy to assimilate.

\section{Acknowledgment}

Thanks teacher Yang and teacher $\mathrm{Hu}$ for giving me careful guidance, without their help and inspiration, I will be very difficult to complete the paper. Due to my limited academic standards, the papers will inevitably be inadequate, welcomes your comments and corrections!

\section{References}

1. http://baike.baidu.com/view/1149510.htm. 
2. Central Committee and State Council on further strengthen agricultural infrastructure construction to promote agricultural development and farmers' income in a number of opinions [z]. 2007-12-31

3. Jingdong Liang. The status, connotation and technical countermeasures of the new rural informatization construction in China [J]. Journal of Nanjing Agricultural University (Social Sciences) . 2006(3):26.

4. http://www.agridata.cn/homepage/ch_intro.asp.

5. Yingbo Li. The structure of China's agricultural information service system $[\mathrm{J} / \mathrm{OL}]$. China's scientific and technical papers onlines http://www.paper.edu.cn/. 